\title{
HACER VISIBLE / HACER AUDIBLE PARALELOS ENTRE EL ESCRACHE DE H.I.J.O.S. (ARGENTINA) Y LA PAH (ESPAÑA)
}

\author{
TO MAKE VISIBLE / TO MAKE AUDIBLE: COMPARISON BETWEEN THE \\ ESCRACHE OF H.I.J.OS. (ARGENTINA) AND THE PAH (ESPAÑA) \\ FAZER VISÍVEL/FAZER AUDÍVEL: PARALELOS ENTRE O ESCRACHE DE H.I.J.O.S \\ (ARGENTINA) E A PAH (ESPANHA)
}

Por:

Magdalena Inés Pérez Balbi

Magister en Estudios Museísticos y Teoría Crítica (UAB)

Universidad Nacional de La Plata, Argentina

magdalena_pb@yahoo.com.ar

Resumen: Este artículo presenta un análisis comparativo del escrache -en Argentina (a través de H.I.J.O.S. Capital y la Mesa de Escrache Popular) y en España (a través de la Plataforma de Afectados por la Hipoteca- Barcelona)- y su despliegue expresivo. En el caso de la Argentina ha sido una herramienta desarrollada para generar condena social a los represores impunes de la última dictadura militar. En los primeros meses de 2013, la PAH utiliza el escrache como estrategia de acción política, y reconoce su origen en la práctica argentina homónima.

El presente trabajo se propone aportar a una genealogía del escrache y sus apropiaciones. Y en particular, reconocer las técnicas de expresión del movimiento y la producción de nuevas escenas de enunciación.

Palabras Clave: Derechos humanos- Argentina- España, Activismo artístico

Abstract: This presents a comparative analysis of the escrache and its expressive deployment, taking as case of analysis the escrache in Argentina (through H.I.J.O.S Capital and Mesa de Escrache Popular) and Spain (through Plataforma de Afectados por la Hipoteca- Barcelona). In the argentinian case, it has been a strategy to generate social justice of unpunished repressors of the last military dictatorship. In early 2013, PAH uses the escrache as a political tool, and acknowledges its origin in the homonymous argentinian practice. 
This article aims to contribute to a genealogy of the escrache and its appropriations. And in particular, to recognize the expression technics of the movement and the production of new scenes of enunciation.

Keywords: Human Rights- Argentine- Spain, Artistic Activism

Resumo: Este artigo apresenta a análise comparativo do escrache e a sua expressão na Argentina, através de H.I.J.O.S Capital e a Mesa de Escrache Popular; e na Espanha, através da Plataforma de Afetados pela Hipoteca- Barcelona. No caso da Argentina, tem sido uma ferramenta desenvolvida para gerar uma condena social aos repressores impunes da ditadura militar. Nos primeiros meses de 2013, a PAH usa o escrache como uma estratégia de ação política e reconhece a sua origem na prática argentina homônima. O trabalho propõe-se a contribuir a uma genealogia do escrache e as suas apropriações. Em particular, reconhecer as técnicas de expressão do movimento e a produção de novos cenários de enunciação.

Palavras-Chave: Direitos Humanos, Argentina, Espanha, Ativismo Artístico.

\section{Introducción}

El escrache es un término que proviene del lunfardo argentino, y que significa denunciar y señalizar culpables, marcar -en su barrio o lugar de trabajo- a quien se considera responsable de algún delito impune. El escrache como procedimiento práctico de producción de justicia (Colectivo Situaciones, 2002), no intenta remplazar la justicia estatal sino ejercer una condena social como práctica política comunitaria. En el caso de la Argentina ha sido una herramienta desarrollada para generar condena social a los represores impunes de la última dictadura militar. Si bien se ha utilizado dentro y fuera de este país, a lo largo de los años ha tomado distintas derivas.

En los primeros meses de 2013, la Plataforma de Afectados por la Hipoteca (PAH) utiliza el escrache como herramienta política, y reconoce su origen en la práctica argentina homónima.

El objetivo general del presente trabajo es aportar a una genealogía del escrache y sus apropiaciones. La PAH no es el primer caso de reapropiación de esta herramienta. En Brasil, Uruguay y Chile (bajo el nombre de funas) el escrache tomó formas propias, manteniendo el objetivo de la condena social a los represores. Durante la crisis del 2001, el bloqueo de los depósitos bancarios movilizó a los sectores medios de la sociedad argentina a escrachar a los bancos como responsables. A partir de esto nos interesa indagar: ¿cómo ha sido re-elaborado el escrache por la PAH? ¿Cómo se articula en el marco más general de la movilización? 
No trazaremos una genealogía exhaustiva sino que nos centraremos en dos casos: los escraches realizados por H.I.J.O.S. Capital y la Mesa de Escrache Popular, y la campaña de escraches de la PAH Barcelona a inicios del 2013. Elegimos estos casos porque H.I.J.O.S. Capital inició dicha práctica, de la misma manera que la PAH Barcelona lo ha hecho en el contexto español.

Y en segundo lugar, como objetivo particular, buscaremos reconocer las técnicas de expresión del movimiento y la producción de nuevas escenas de enunciación.

Para esto, partimos del supuesto de que cada escrache (como cualquier estrategia político-estética de movilización) se integra en un despliegue expresivo del movimiento que no puede pensarse fuera de la movilización y la intervención en el espacio público. No es exclusivamente (audio)visual sino que se integra (se performativiza) con/en los cuerpos manifestantes y en la ocupación del espacio público. Y a su vez, el momento de la movilización-escrache es el momento en el que confluyen, como espacio-tiempo cúlmine de visibilidad de la protesta, una serie de dispositivos comunicacionales, de modos de enunciación que pueden no haberse pensado exclusivamente para esa instancia. Desde esta perspectiva, recuperamos el término de activismo artístico como hibridación de herramientas visuales/ artísticas para la acción política. No es la mera producción de un arte político (en el que "lo político" actuaría como adjetivo, como valor agregado de una producción ontológicamente no-política), sino la concepción del arte y la política como divisiones de lo sensible, como esferas no autónomas en convergencia (Expósito, Vindel \& Vidal, 2012; Rancière, 2010).

\section{La herramienta en situación. Breve recorrido histórico de cada movimiento.}

Comprender el surgimiento de los escraches, requiere revisar brevemente las coyunturas en las que se desarrollan ambas experiencias.

En el caso de la Argentina, el Plan Sistemático de Desaparición Forzada de Personas fue implementado durante la última dictadura militar en Argentina (1976 - 1983). La cifra oficial de desaparecidos es de 30.000 personas y más de 500 hijos apropiados, de los cuales 116 han podido restituir su identidad, gracias a la labor de Asociación Abuelas de Plaza de Mayo y el Equipo Argentino de Antropología Forense.

El gobierno encabezado por el Dr. Raúl Alfonsín, que en 1985 había promovido el juicio y procesado a las tres juntas militares del periodo 1976-1983, promulgaba en 1986 y 1987 la Ley de Punto Final y la Ley de Obediencia Debida. Estas leyes dejaban en libertad, desprocesaban, e impedían enjuiciar a cientos de represores responsables de desaparición y tortura. Más tarde, con los indultos decretados por Carlos S. Menem entre 1989 y 1990, quedaban en libertad, entre otros, los jefes de las fuerzas armadas (J. R. Videla, E. Massera, F. Galtieri y R. Viola) y algunos de los funcionarios más emblemáticos de la dictadura militar, como J. A. Martínez de Hoz (Ministro de Economía del primer gobierno de facto). 
En la década del '90, en pleno retroceso de la organización popular y con la implementación rigurosa del programa neoliberal, el panorama en términos de verdad y justicia era muy distinto al actual. H.I.J.O.S. nace en un momento en que las organizaciones de DDHH parecían condenadas al fracaso en cualquiera de sus reclamos. La agrupación tiene su hito fundacional en 1994, en un acto homenaje a los muertos y desaparecidos por el Terrorismo de Estado en la Facultad de Arquitectura y Urbanismo de la Universidad Nacional de La Plata, organizado por un grupo de ex alumnos, como primer momento de visibilidad pública como hijos de desaparecidos. Se sucedieron varios encuentros hasta la fundación de la agrupación en 1995. El nombre resumía los principios básicos de la agrupación: exigencia de justicia, necesidad de reconstruir la historia personal, rescatar el espíritu de lucha de sus padres (más allá de las diferencias entre las organizaciones políticas que integraron), y búsqueda de los hermanos apropiados y privados de su identidad. Entre ese año y el siguiente se formaron distintas regionales (La Plata, Córdoba, Rosario, Santa Fe, etc.) y, por otra serie de homenajes, se constituía H.I.J.O.S. Capital. Al cumplirse un año, ya contaban con 14 regionales y más de 600 integrantes.

En 2003, durante el primer gobierno del Frente Para la Victoria (FPV), el Congreso de la Nación declara nulas las leyes de Punto Final y de Obediencia Debida. Esto permitió reactivar las causas judiciales y procesar a una gran cantidad de represores por su responsabilidad en la dirección de grupos de tareas, torturas, desaparición forzada de personas y apropiación de hijos e hijas de desaparecidos. Los Juicios por la Verdad, iniciados en 1998, constituían el precedente.

H.I.J.O.S. consolida una concepción (y práctica) de la acción política distinta de la lógica partidaria tradicional. Como menciona (Zibechi, 2003), si la política tradicional separa la fiesta de la protesta y la forma del contenido, en H.I.J.O.S. ambos tiempos se fusionan, y conviven la organización política y la comunidad de afectos. Esto se refuerza en una identidad construida y reconocida desde la participación en el colectivo. Ser hijos de desaparecido/s remite al lugar de víctima. Ser un Hijo por la Identidad y la Justicia, contra el Olvido y el Silencio, se transforma en subjetivación política.

H.I.J.O.S. se ubica en lo que Svampa (2010) denomina matriz político-ideológica de nueva narrativa autonomista, que incluye organizaciones de desocupados, asambleas barriales, organizaciones de DDHH, fábricas recuperadas, asambleas socio-ambientales, numerosos colectivos culturales y nuevos activismos sindicales. Esta matriz se fundamenta en la afirmación de la autonomía, la horizontalidad y la democracia por consenso. Y se define como narrativa autonomista porque "se construye como un relato identitario, de producción del sujeto, en el cual cuenta la experiencia personal de los actores (antes que una inscripción en la comunidad, el pueblo o la clase social)” (Svampa, 2010, p. 19).

La inclusión de estos análisis no es arbitraria. Cobra sentido al entender la práctica del escrache como práctica política innovadora y como manifestación en el espacio público diversa de la concentración y/o movilización tradicional, pero también para comprender los paralelos con las líneas de acción de la PAH. 
La PAH se funda en Barcelona febrero de 2009, y tiene dos antecedentes directos. Uno de ellos es el movimiento V de Vivienda, surgido en 2006 a partir de una convocatoria vía mail a concentrar en distintas plazas del Estado español bajo el lema de "No tendrás casa en la puta vida". A partir de esta acción el movimiento se fue consolidando, articulando las movilizaciones y debates sobre el derecho a la vivienda y el problema de la especulación inmobiliaria (Alemany \& Colau, 2013).

El otro son las ODS (Oficinas de Derechos Sociales) del Ateneu Candela de Terrassa (Barcelona) que trabajaban en tres áreas problemáticas: trabajo, vivienda y migración. Hacia 2008, los primeros casos de desahucios por hipotecas impagas, los lleva a articular acciones con Ahorcados por la Hipoteca (de Madrid) y luego con el grupo en torno a $\mathrm{V}$ de Vivienda.

V de vivienda había empezado a rebatir públicamente los mitos que el gobierno, en connivencia con bancos y constructoras, había levantado en épocas de bonanza económica. El acceso al crédito, acompañado de una desregulación del mercado financiero y la modificación de la legislación sobre el uso del suelo (Ley del Suelo o Ley del todo urbanizable, aprobada por mayoría absoluta del Partido Popular -PPen 1998) permitió que, al menos durante una década, la ciudadanía accediera a la vivienda propia. Esto, además, se sustentaba en un imaginario (construido durante años por ministros de Vivienda y de Economía, políticos de todos los partidos y expertos) en el que ser propietario era un símbolo de status y seguridad social (Alemany \& Colau, 2013).

La burbuja inmobiliaria y el sobreendeundamiento de la población española, al converger con la crisis financiera, la recesión económica y las altas tasas de paro, llevaron a que la letra chica del sistema de hipotecas hiciera estragos. Además, la legislación española no contempla la dación en pago. La deuda recae sobre la persona endeudada (y sus avales) y no sobre el bien, por lo que la entrega del inmueble. La persona desahuciada no sólo pierde su casa sino que conserva una deuda de por vida que sigue acumulando intereses.

Por otro lado, el crecimiento de la PAH no puede entenderse sin el proceso del 15M. Al levantarse la ocupación de las plazas y diluirse el fervor inicial del movimiento, la PAH aparecía como una organización en marcha a la cual sumarse o activar en el contexto propio, y el problema de las hipotecas resultaba sintomático de la estafa o genocidio financiero y del fracaso del modelo democrático. La PAH pasó de tener 6 sedes en Catalunya y Murcia a inicios de 2011, a 144 en todo el estado español a principios de 2013.

A diferencia de H.I.J.O.S., la PAH no es una organización integrada inicialmente por los propios afectados. El primer año prácticamente se centra en un proceso de formación, para comprender la Ley Hipotecaria, las alternativas que el estado provee y los vericuetos administrativos y legales para negociar deudas y retrasar desahucios. 
$\mathrm{Al}$ iniciar el trabajo con afectados, comenzaron a organizar asesorías colectivas y acciones en bancos. Las primeras consistieron en asesoramiento respecto de trámites, formularios y vías legales de acción ante la orden de desahucio o la situación de impago de hipoteca, además de contención emocional. La práctica del asesoramiento colectivo es parte del proceso de empoderamiento de los afectados, que van integrándose y consolidando el movimiento.

Las acciones en bancos también son colectivas, y pueden entenderse como una suerte de escrache. Más allá de que cada afectado gestione su propia renegociación de deuda o dación en pago, estas acciones colectivas consisten en ingresar al banco en horario de atención al público, explicar a empleados y clientes lo que esa entidad financiera está haciendo con sus hipotecados, interrumpir la actividad normal de la sede, llenando de pegatinas y volantes el espacio, e intentar gestionar daciones en pago del conjunto de hipotecas en esa entidad.

La PAH ha ido organizando sus campañas (líneas de trabajo) paulatinamente, como respuestas a problemáticas concretas. Estas son: Stop desahucios (movilización solidaria para frenar desalojos), Obra Social (ocupación de viviendas vacías en manos de financieras o fruto de ejecuciones hipotecarias) y la Iniciativa Legislativa Popular (ILP). Esta última fue lanzada en 2011 por un grupo promotor de varias organizaciones (entre las que estaba la PAH) y contenía tres demandas mínimas: dación en pago retroactiva (la entrega del inmueble hipotecado condona la deuda), paralización de los desahucios que afecten a viviendas habituales y posibilidad de permanecer en el inmueble bajo el régimen de alquiler social (pagando hasta el 20\% de su ingreso familiar). En febrero de 2013, cuando la ILP se presentó formalmente en el congreso, el PP (a cargo del poder ejecutivo y con mayoría parlamentaria) declaró que no permitiría su tratamiento y, una vez aceptada, que votaría en contra. Esta negativa fue el detonante para la campaña de escraches, que funcionarían (en conjunto con movilizaciones masivas) como estrategia de presión social y como herramienta de señalización, en cada ciudad, a los responsables de que el genocidio financiero y la sangría de los desahucios se perpetuara.

\section{Sin justicia y con desahucios. Origen y despliegue de los escraches.}

\section{a) De la Comisión a la Mesa. El escrache de H.I.J.O.S.}

H.I.J.O.S. realiza los primeros escraches en 1996. Dos años mas tarde, ya son movilizaciones masivas y de gran repercusión mediática.

A pesar de la poca movilización popular y retroceso en las condenas por delitos de lesa humanidad que mencionábamos anteriormente, existía un consenso mínimo respecto de la impunidad de los crímenes de la dictadura, sobre todo desde que Adolfo Scilingo (ex oficial de la marina de guerra) confesara públicamente en 1995 la existencia de los vuelos de la muerte (práctica de desaparición forzada en la que los detenidos, atados y sedados, eran lanzados al Río de la Plata y Mar Atlántico desde aviones) develando además la complicidad con la Iglesia católica argentina (Verbitsky, 1995). 
La logística y práctica del escrache ha cambiado desde su inicio, por lo que pueden definirse dos etapas. La primera, desde 1996 a 1998 (momento de la formación de la MEP) y la segunda, desde esa fecha en adelante.

En la primer etapa, el escrache consiste en una movilización ruidosa, festiva y que a su paso va dejando huellas (carteles, señalizaciones, esténciles) desde un punto de encuentro hasta el domicilio o lugar de trabajo del represor. Ese domicilio o lugar de trabajo marca el momento del escrache propiamente dicho, que consiste en señalizar con témpera roja (como bombardeo), pegar carteles, volantear, realizar intervenciones artísticas, cantar canciones alusivas al escrachado, leer el comunicado correspondiente y luego desconcentrar. Bajo el lema de Juicio y Castigo, los escraches se caracterizan por elegir figuras mediáticas y representativas del terrorismo de Estado, o centros clandestinos de detención (CCD) relevantes. Con el objetivo de lograr mayor repercusión mediática, se realizan en fechas estratégicas. Si bien se lleva adelante un trabajo territorial de difusión y convocatoria previa, no hay todavía un trabajo conjunto con agrupaciones, y/o vecinos del barrio. Aun existiendo una progresiva colaboración de otras organizaciones o colectivos, sus aportes tienen voz, pero no voto. Los escraches son pensados, promovidos y realizados por la Comisión Escrache de H.I.J.O.S., es esta organización la enunciadora.

En la segunda etapa, el escrache deja de ser una operación efímera e intempestiva (aun cuando tuviera un desarrollo previo al interior de la Comisión), para transformarse en un trabajo territorial de construcción colectiva. La MEP es un espacio de trabajo local en red con organizaciones sociales diversas (centros culturales, centros de estudiantes, murgas, asambleas, etc.), privilegiando el trabajo barrial en lugar de la masividad de la movilización-escrache. Las sedes de trabajo dejan de ser los espacios de H.I.J.O.S. y pasan a ser, por ejemplo, los centros culturales. Esto implica, sin intención explícita, que H.I.J.O.S. deje de ser el único enunciador y productor del escrache.

El reclamo de Juicio y Castigo es, de cierta forma, relegado en pos de una construcción social y comunitaria de la condena social. Esto tiene dos consecuencias directas en la temporalidad del escrache: en primer lugar, las fechas ya no las define una agenda mediática ni la urgencia de alguna efeméride, sino el propio proceso barrial; y en segundo lugar, una vez finalizada la marcha y señalización, el escrache se continua en la condena social. Cuando el comerciante del barrio se niega a venderle al represor, el consorcio decide no limpiar la fachada del edificio escrachado, el represor es despedido de su trabajo o le quitan la matrícula médica, es cuando la condena social se hace efectiva, y, más allá de finalizado el proceso de la MEP, el escrache continua.

Lo que permanece como una constante en ambas etapas del escrache es la característica carnavalesca y festiva de la movilización, generada a través de distintas acciones que se van configurando como herramientas permanentes, como parte de un lenguaje propio. A fines descriptivos, sintetizamos divididas disciplinarmente, pero entendemos que en la práctica, se retroalimentan y funcionan en sincronía: 
- Intervenciones teatrales- escénicas:

La puesta en escena o teatralidad ha tenido dos vertientes claras: la producción de marionetas-muñecos monumentales y las performances realizadas por el grupo Etcétera... caracterizadas por un surrealismo grotesco (Fig. 1). El trabajo de Etcétera... en los escraches, y su continuidad en la Internacional Errorista, han sido ampliamente reseñados y analizados en diversos textos (Creisher y Sickmann, 2004; Holmes, 2009; Longoni, 2005, 2007; Schindel, 2008; Zuckerfeld, 2011) por lo que nos limitaremos a señalar algunos aspectos relevantes para nuestro trabajo.

A medida que los escraches se fueron masificando, la estrategia de representación cambió de finalidad. Inicialmente, el objetivo de estas representaciones grotescas del terror, era lograr visibilidad mediática y generar empatía con el transeúnte y el participante del escrache, descontracturando la movilización a través de un relato humorístico. Esa estrategia sirvió luego para distraer a la policía que custodiaba el vallado frente al lugar del escrache. Al momento de lanzar bombitas con pintura roja, el foco de atención debía estar en otro lado. Este bombardeo en rojo es, además, una apropiación de la estrategia para manchar (y obstruir la visión) a tanques en manifestaciones estudiantiles chilenas de la época (Zuckerfeld, 2011). El rojo es la adaptación que la Comisión de Escrache opera para reforzar la acusación de asesino al escrachado.

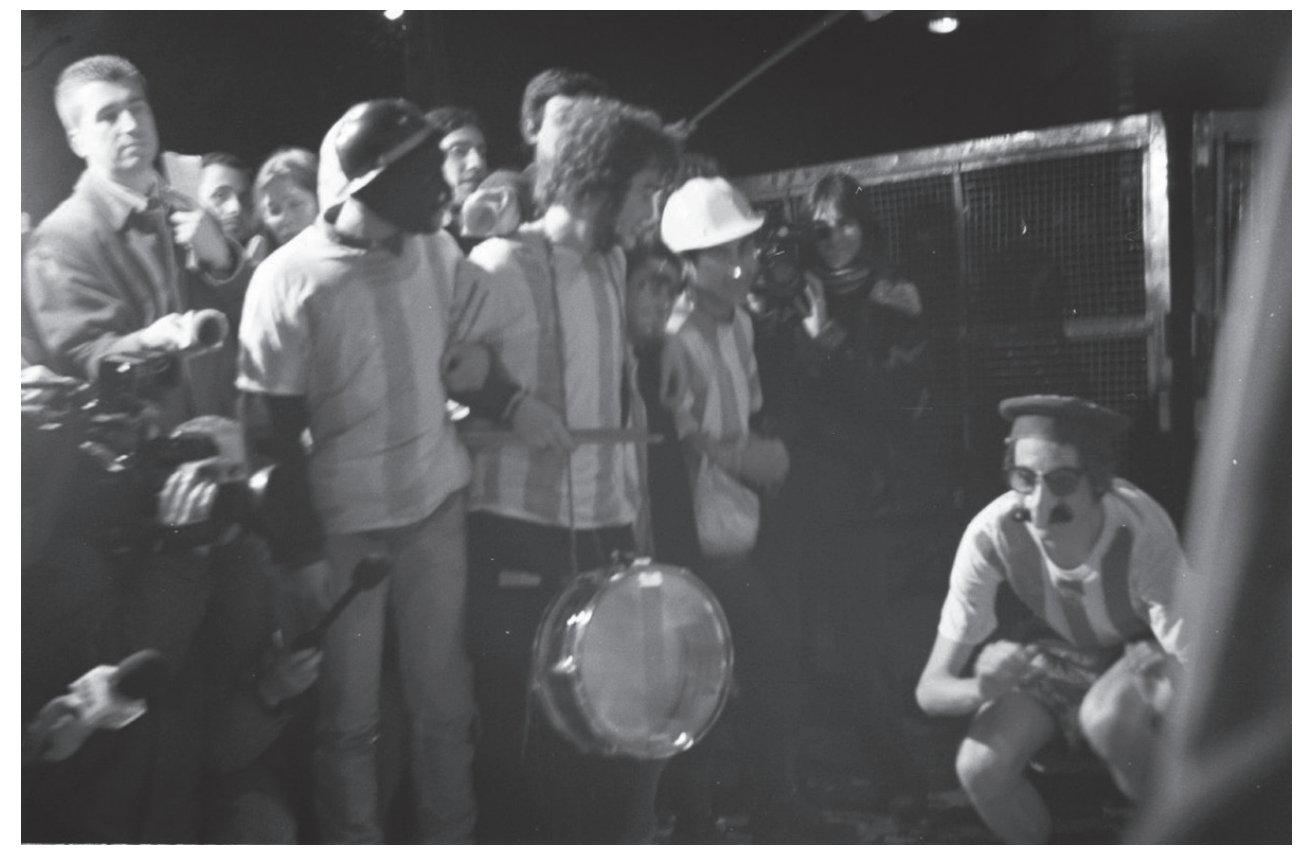

Figura 1. Acción de Etcétera... (sobre intervención del GAC). Escrache a Galtieri, Buenos Aires, 1998. Fuente: www.grupoetcetera.wordpress.com 
Por otra parte, el acercamiento de Etcétera... a H.I.J.O.S. (desde 1998) no responde solamente a las historias de vida de algunos de sus integrantes, sino también a una complicidad generacional y a la búsqueda de un espacio donde se pudiera construir un pensamiento político nuevo (Loreto Garín en Cresisher Sickmann, 2004, p. 283).

\section{- Intervenciones gráfico-artísticas:}

De la misma manera que el despliegue teatral se identifica con Etcétera..., el desarrollo visual (cuando no el escrache en si mismo) se identifica con el GAC (Grupo de Arte Callejero). El grupo fue construyendo la iconografía completa, desde volantes a señales viales (de Juicio y Castigo, de señalización de represores y CCD) y a los afiches de Aquí viven genocidas (Holmes, 2009; Longoni, 2005, 2007; Rafaela Carras (GAC), 2009; Schindel, 2008). Esa identidad/identificación escrache- H.I.J.O.S.- producción del GAC es tal que la imagen de Juicio y Castigo se ha transformado en el logo de la organización. Destacamos entonces que, en toda su producción en/para los escraches, el GAC trabaja la visibilización y señalamiento pero alejándose de una estética de denuncia. El programa de señalización vial es parte del escrache, pero se funde en el espacio público y en la polución visual contemporánea, logrando una permanente tensión entre invisibilidad y extrañamiento. Incluso permaneciendo como señalización más allá del momento de la movilización-escrache.

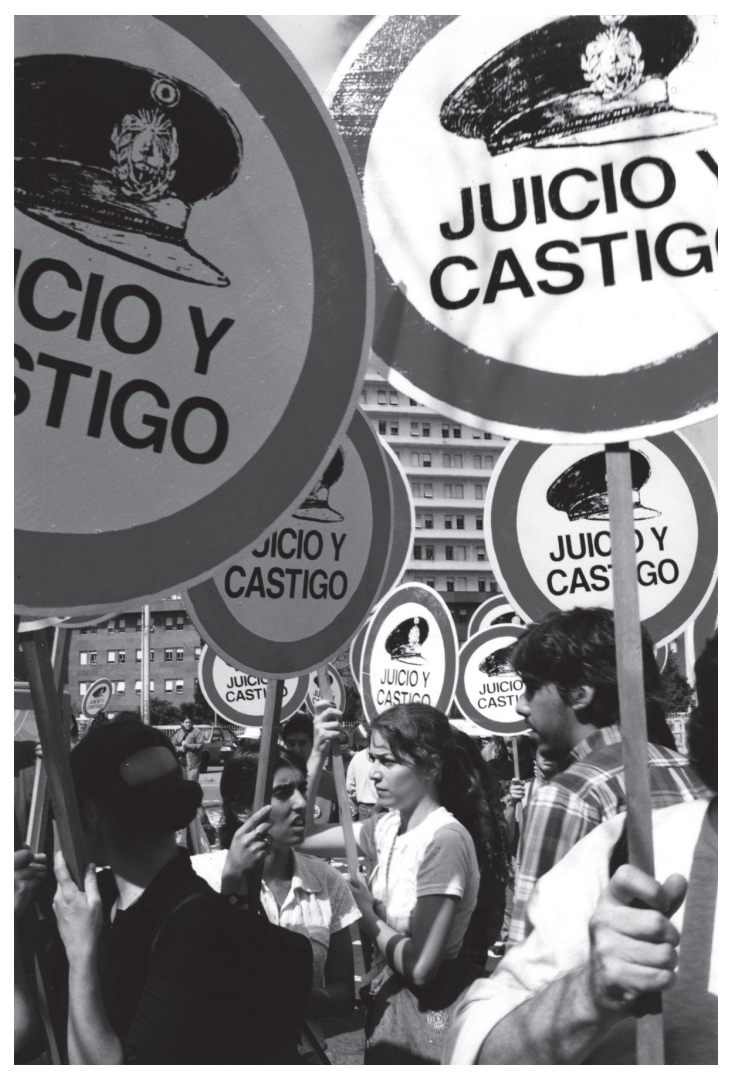

Figura 2. Pancartas de Juicio y Castigo (GAC) Fuente: Flickr del GAC. https: / /www.flickr.com/ photos/gacgrupodeartecallejero/ 
Suele identificarse el despliegue expresivo de los escraches con la señalización del GAC, las performance de Etcétera... y/o la mancha roja sobre la residencia del escrachado. Esto genera, a nuestro entender, una doble simplificación: en primer lugar, reduce el escrache a lo visual- teatral (a "lo que se ve") pero sobre todo, lo reduce al momento de la movilización y el escrache propiamente dicho, invisibilizando el proceso territorial previo y la condena social posterior. Esto equipararía el escrache popular de H.I.J.O.S. a cualquier otra forma de escrache, intempestiva y unilateral.

-Intervenciones sonoras:

En Argentina, toda movilización se caracteriza por el sonido de percusión. No es sólo un bombo que dirige la marcha, sino muchos bombos, tambores y redoblantes los que se escuchan al mismo tiempo. En las manifestaciones y cortes de calle el ruido, la percusión y los megáfonos son una constante, y no una excepción o estrategia estéticopolítica novedosa. Este contexto ayuda a entender el rol de la murga.

La murga porteña consiste en una práctica artística que combina teatralidad, danza y música y canto. Está integrada por músicos, bailarines y fantasías (aquellos que portan los estandartes) cuya actuación se organiza como desfile y tiene su momento más álgido durante los corsos de carnaval. Es, además, una organización popular, y en muchos casos es una forma de inserción social en barrios populares. El nombre de cada murga, generalmente, destaca la pertenencia al barrio (Los cometas de Boedo, Los caprichosos de Mataderos, etc.), y los trajes llevan la impronta de cada murguero con bordados que identifican aficiones futbolísticas, musicales y barriales. Las letras y las actuaciones de las murgas tienen, además, un fuerte componente coyuntural y político.

En Argentina, el feriado del carnaval (y por ende, la posibilidad de su festejo masivo) fue prohibido definitivamente durante la última dictadura militar (decreto ley 21329/76) y se restableció recién en 2010. Desde los años 90 las murgas, en distintas coordinadoras independientes, se han movilizado por la recuperación del feriado del carnaval. Resulta evidente que la murga sea, entonces, parte indiscernible de los escraches.

\section{b) El escrache de/en la PAH}

La campaña de escraches de la PAH se anuncia (en la web oficial) como un bloque de acciones en dos etapas: una primera de acercamiento e información, y una segunda de señalización. Sin embargo, éstas se modifican de acuerdo a los hechos. Ante la negativa del PP de discutir y aprobar la ILP, en la PAH se empiezan a discutir distintas respuestas. Las diferentes propuestas de acción y movilización luego se identifican con el escrache argentino. Es decir, las acciones son pensadas por fuera de la categoría a la que luego se adscriben, e incluso, contaminadas por distintas influencias. Así, no 
sólo aparece la referencia a la práctica argentina, sino también recuperan la acción de una organización pacifista holandesa que, durante la Guerra Fría, se organizó para informar personal y sistemáticamente a diputados y convencerles de que debían oponerse a la instalación de misiles estadounidenses en su país. Previo al escrache, se convocaba a los diputados a participar de las asambleas de la PAH. Partían de la premisa que, si un diputado (responsable de votar a favor o en contra de la ILP) conociera lo que esa ley implica en la vida de los afectados, seguramente acordaría con las tres medidas mínimas.

Dado que los diputados, como se suponía, no respondieron ni participaron, se iniciaba la segunda fase de la campaña, nombrada como PAHdagogía, que consistía en concurrir al domicilio del diputado para explicarle, de voz de los propios afectados, la importancia de la ILP. La aceleración de los plazos de tratamiento de la ILP y la respuesta criminalizadora de parte de Rajoy y de distintos representantes del gobierno nacional, transformó esta segunda etapa en el escrache propiamente dicho.

Las herramientas visuales fueron diseñadas por el colectivo Enmedio, que ya había realizado acciones colaborativas con la $\mathrm{PAH}$, además de otras producciones en relación a la problemática del acceso a la vivienda.

El despliegue visual consiste en dos elementos básicos: los botones verde y rojo, en referencia a los botones que pulsan los diputados para votar a favor o en contra de un proyecto. El verde, con el lema "Si, se puede". Sobre el perímetro, se enuncian las tres medidas mínimas: detener los desahucios, dación en pago retroactiva, alquiler social. Tanto el color como el lema identifican a la PAH. El botón rojo decía "Pero no quieren", en clara alusión a la explícita negativa del PP.

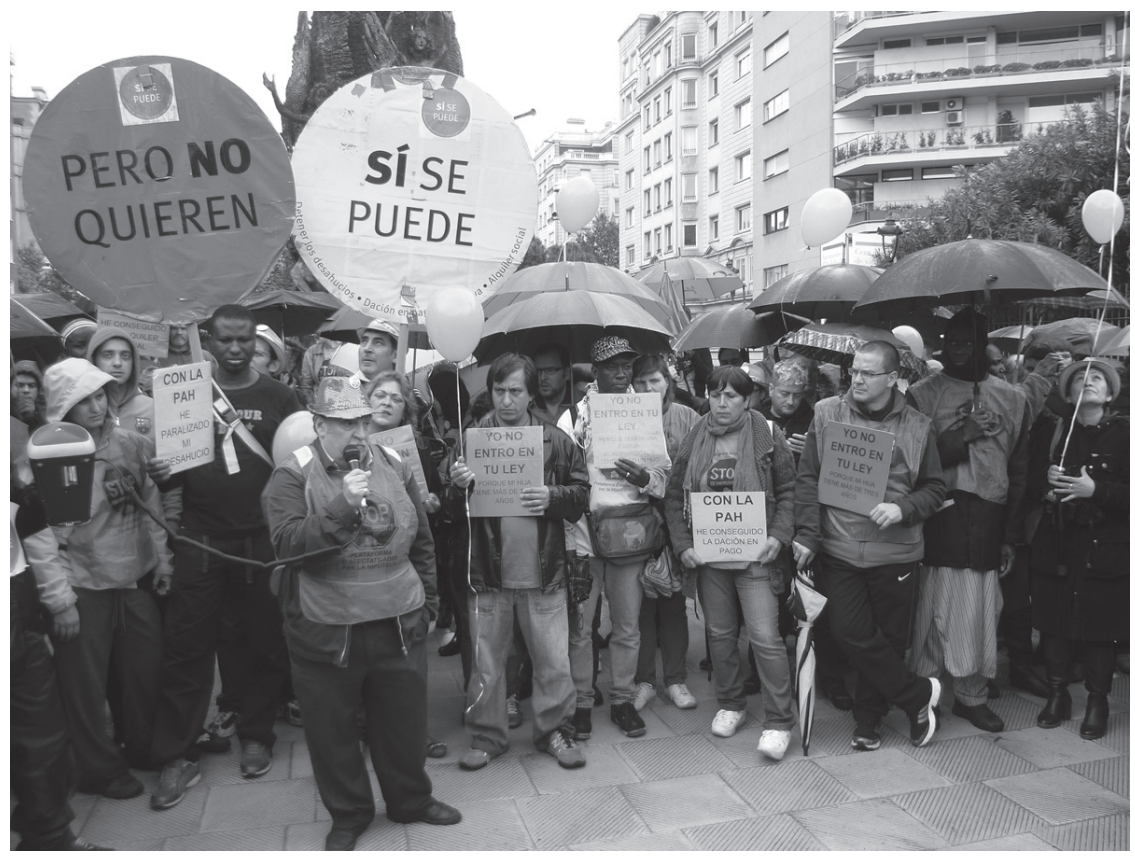

Figura 3. Testimonios durante un escrache de la PAH. Barcelona, abril 2013. Registro propio. 
En pos de una práctica DIY (do it yourself), el kit completo con instrucciones de montaje podía descargarse de la web. El objetivo era generar una iconografía que diera identidad al escrache, pero que no requiriera de saberes técnicos especializados para su puesta en práctica. Junto con ello, un protocolo de acción permite conocer cual es el espíritu del escrache, la relación con los vecinos y los pasos a seguir.

El botón verde excede el tiempo del escrache porque se piensa como un elemento de identificación positiva del movimiento y de todos aquellos que adhieran a la aprobación de la ILP. Es así que, en forma de pegatinas o pequeños afiches, el botón verde aparece en tiendas, casas, pines, etc. De la misma manera que la señal vial de Juicio y Castigo termina identificando a H.I.J.O.S. mas allá del escrache, el botón verde de Si se puede identifica a la PAH mas allá del escrache. En ambos casos, la autoría (del GAC y de Enmedio respectivamente) se diluye en la repetición de la imagen.

El factor mediático y de difusión del escrache es un aspecto fundamental en la PAH.A diferencia del proceso de H.I.J.O.S., las redes sociales y las aplicaciones para móviles han permitido difundir instantáneamente imágenes de los escraches y hacer transmisión en directo vía streaming de la lectura de comunicados, testimonios de afectados y acciones en bancos.

Si H.I.J.O.S. se negaba a supeditar la planificación y desarrollo del escrache a su impacto mediático (en términos de depender de medios de comunicación masivos y hegemónicos), los escraches de la PAH se piensan desde una acción de autodifusión y construcción de una narración propia de los hechos. El acceso a las redes sociales y el desarrollo de las nuevas tecnologías y dispositivos comunicacionales de fácil manipulación, permiten esta instantaneidad que excede el relato institucional (en páginas web de la PAH, perfil de Facebook, Twitter y canal de YouTube e incluso transmisión vía streaming) sino que se multiplica al ser re-posteado, comentado y compartido por miles de usuarios.

El escrache de la PAH incorpora otro aspecto al evidenciar la constitución de clase de los barrios de Barcelona. Exceptuando los escraches a la sede del PP (en el barrio de l'Eixample), y en la estación de tren de Sants (para recibir a los diputados a su regreso de Madrid) el resto de las acciones han sido en los barrios altos (Sarrià- Sant Gervasi, Prat de Llobregat). Esto marca la distancia territorial entre las zonas donde viven los diputados y aquellas donde se producen los desahucios.

Por último, cabe destacar que ambos usos del escrache se desarrollan en momentos de descrédito profundo con el sistema democrático-representativo. Tampoco es casual que ambos formen parte de un acto de empoderamiento. El escrache es parte de una experiencia de pasaje del padecimiento y la identificación como víctima a la experimentación de una subjetividad activa y productiva (Colectivo Situaciones, 2002; Zibechi, 2003). Es parte del tránsito de ser "hija o hijo de desaparecidos" a ser parte de H.I.J.O.S., así como en la PAH se integra a un proceso que va de la estigmatización del endeudado a la acción política. 


\section{Las políticas visuales de los movimientos}

El despliegue expresivo de los escraches no puede leerse como una acción aislada ni como una ocurrencia de una sola agrupación, sino como parte de las políticas visuales del movimiento de DDHH en Argentina. Los íconos y recursos que las forman, y que incluso identifican estas luchas, son fruto de una construcción paulatina y tienen su origen, muchas veces, en simples respuestas prácticas a un problema específico: las rondas de los jueves de las Madres de Plaza de Mayo fueron la estrategia para evitar la prohibición a la reunión, y los pañuelos (pañales de tela) la seña para reconocerse entre la gente. Aunque hoy puedan entenderse como una práctica performática de la memoria y del duelo (Schindel, 2008; Taylor, 2002, 2006), no se originaron con una intencionalidad estética de manifestación pública. De la misma manera, el uso de fotografías va adecuando sus formatos según el momento del movimiento, pasando de ser pequeñas fotos que se portan sobre el cuerpo, a ampliaciones en la manifestación (como pancartas) hasta llegar a los recordatorios del periódico Página/12 (Longoni, 2010).

La persistencia y transformación de esos actos y objetos termina integrándolos al repertorio del que también se nutre el escrache, sea para continuarlo o para funcionar como contrapunto.

El Siluetazo, acción coordinada entre artistas (Kexel, Flores y Aguerreberry) y la Asociación Madres de Plaza de Mayo para la Tercera Marcha de la resistencia (1983) y rápidamente desbordada y multiplicada, también se integra en esta tradición. Constituye el momento de mayor impacto de un recurso (la realización de siluetas) que ya se utilizaba, y continuará utilizando, de diversas maneras (Longoni \& Bruzzone, 2008; Longoni, 2010) ${ }^{1}$.

Podríamos decir que, tanto las siluetas como las fotos, se encuentran todavía en una instancia de la representación de los desaparecidos, relacionadas a una necesidad y visibilidad de los hechos, a darles un rostro, una densidad numérica, una presencia en el espacio público y, por ende, en el discurso sobre lo público. El escrache se integra, entonces, en esta trama de pañuelos, rondas, marchas, siluetas y otras marcas en la calle. Pero parte de una diferencia radical: ya no es una estrategia de representación sino de señalamiento. Es decir, no pone el foco en las víctimas sino en los victimarios y sus cómplices. Las herramientas visuales y artísticas no giran en torno a la representación de los desaparecidos sino a dos aspectos fundamentales. El primero es redirigir la atención hacia la logística del terrorismo de estado, sea por sus operadores (represores y cómplices) como por la huella en los espacios hoy cotidianos (Aquí viven genocidas, señalización de ex CDD) y el reclamo de justicia (sea Juicio y castigo o la condena social). Y el segundo es mantener el carácter festivo y carnavalesco (la murga, el color del despliegue visual, los muñecos, la teatralización grotesca). 
De la misma manera, podemos enmarcar el escrache de la PAH en un conjunto de intervenciones y estrategias de acción en el espacio público. Algunas son previas al escrache de la PAH, y otras funcionan en sincronía.

Dentro de las acciones previas, destacamos dos que consideramos fundamentales:

El primero fue Supervivienda, un superhéroe múltiple (es decir, encarnado por distintas personas, de distinto género) que irrumpía en presentaciones públicas de los entonces candidatos a elecciones municipales de 2007. El objetivo era interferir en la difusión mediática de dichos actos, reclamando (a través de pancartas en cartón) que la "vivienda quedara fuera del mercado, como la sanidad y la educación”. En la capa el personaje llevaba el número 47, por el artículo constitucional que (aún hoy) se esgrime para reclamar la responsabilidad del estado en garantizar el derecho a la vivienda. La combinación de amarillo y negro se repetía en los afiches de $\mathrm{V}$ de Vivienda, y en la acción "No tendrás casa en la puta vida”. Amarillos también eran los globos que se pinchaban, metáfora de una burbuja inmobiliaria que se destruía.

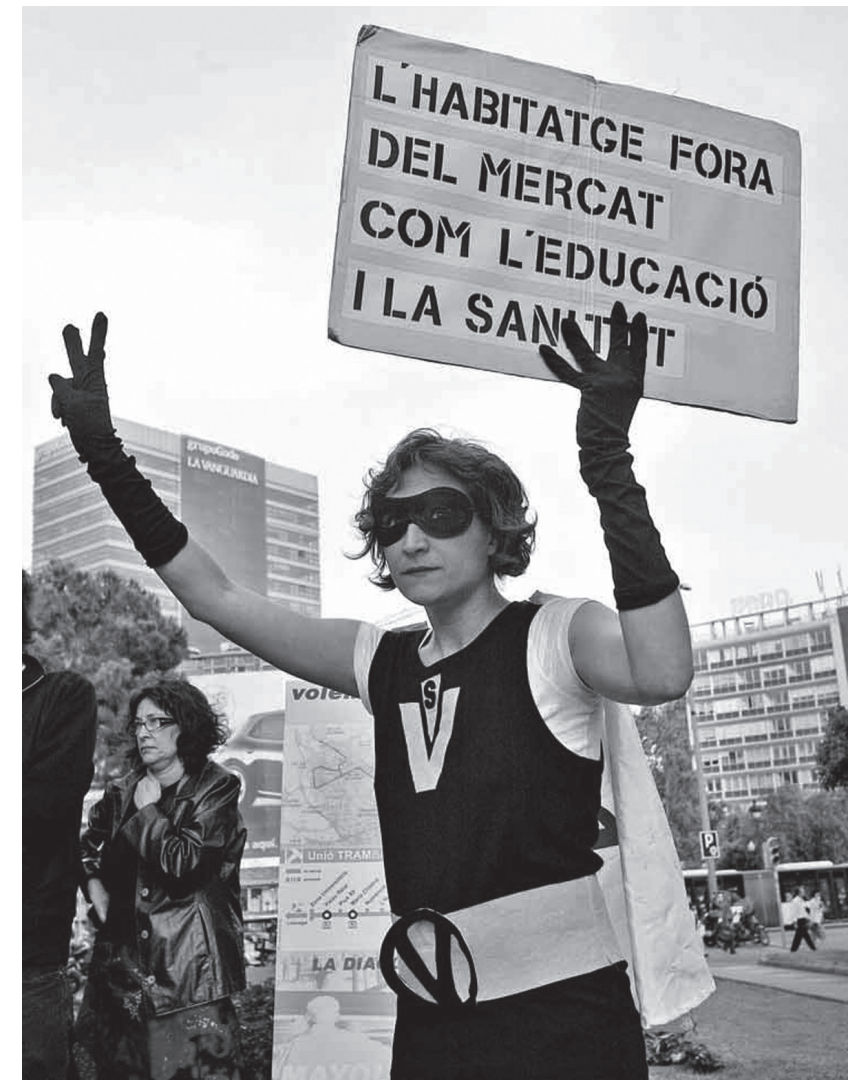

Figura 4. Supervivienda, 2009. Fuente: Perfil de Facebook de Supervivienda (https://www.facebook.com/pages/Supervivienda/53206302023?sk=timeline) 
Como mencionan Alemany \& Colau, (2013) lo que distinguía al movimiento V de Vivienda no era el contenido de la información, sino el modo de comunicación. Para deconstruir el discurso hegemónico sobre las posibilidades de crédito y de acceso a la vivienda, este movimiento recurrió al humor, a la ficción y las intervenciones festivas y multitudinarias.

El segundo es una acción única, que se llamó "No tendrás casa en la puta vida”. A partir de e-mails y videos publicitarios, se convoca a asistir frente al ayuntamiento de cada ciudad, el 6 de Octubre de 2007, para "Batir el record mundial de gente gritando: No tendrás casa en la puta vida". Un "putómetro" interactivo registraría los decibeles del sonido para fiscalizar el nivel de enojo colectivo (así como de potencia de acción, agregaría yo). Nuevamente, el objetivo era hacerse audible y visible colectivamente, desde el humor y la ironía, en un ambiente festivo y alegre.

Como parte de las acciones contemporáneas o en trama con los escraches, destacamos:

- "No somos números": fue una acción coordinada entre el TAF! (Taller de Acción Fotográfica, coordinada por integrantes de Enmedio) y la PAH, realizada en enero de 2013, que consistió en la impresión de postales con rostros y datos de desahuciados por el banco Caixa Catalunya, en las que podían escribirse mensajes al dorso destinados a esta entidad bancaria. Los pie de foto describían nombre, edad, y actividad del afectado y el lema "Va a ser desahuciado por Caixa Catalunya". Al dorso, como la hipoteca había afectado sus vidas.

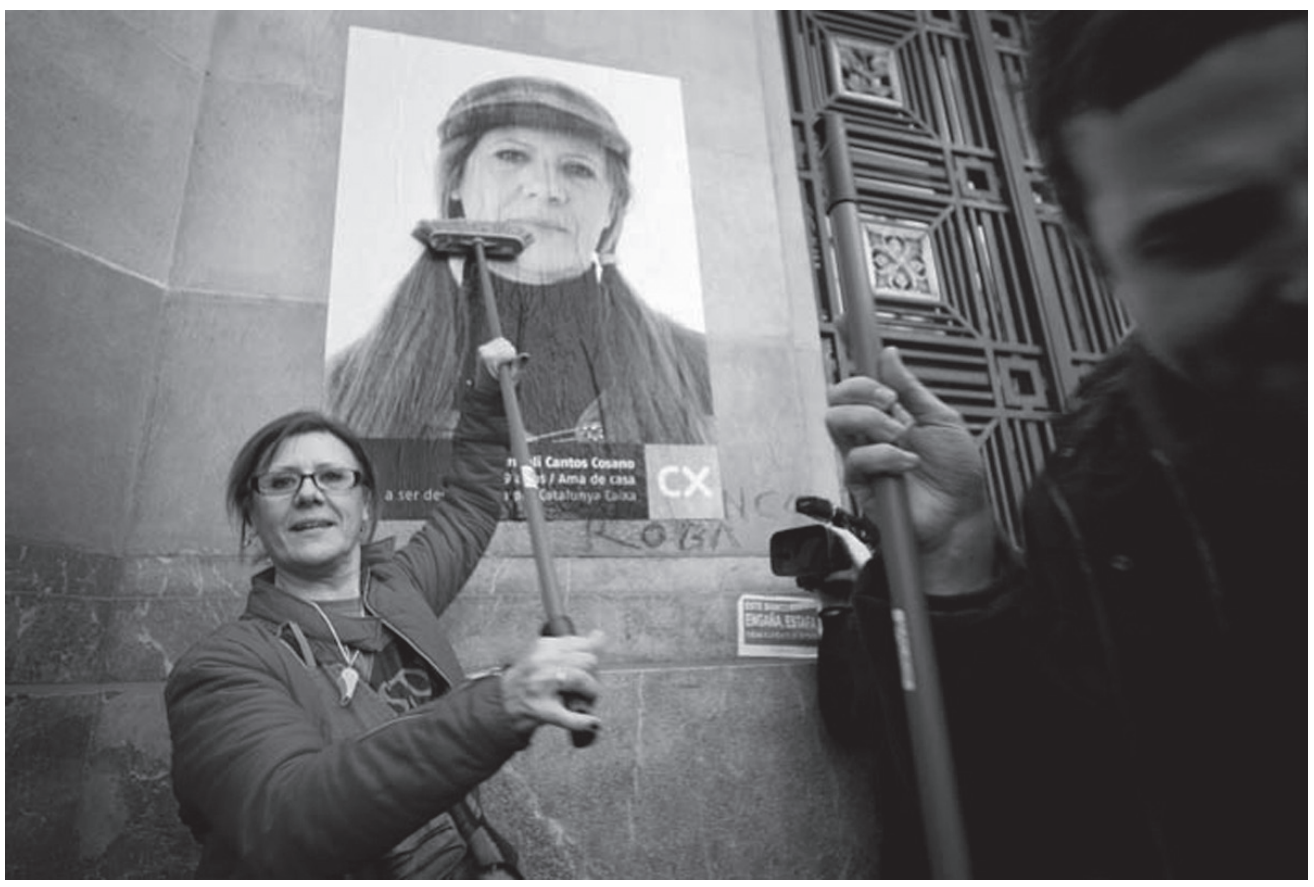

Figura 5. Intervención No somos números. Caixa Catalunya, Barcelona, 2013. Fuente: Enmedio: http: / / www.enmedio.info/postales-y-retratos-fotograficos-contra-los-desahucios-de-calatunya-caixa/ 
Esas mismas fotos se imprimieron como gigantografías para ser pegadas en las paredes del banco. En distintas movilizaciones y acciones, continuaron apareciendo esas imágenes que buscan dar cuenta de las historias de vida detrás de las hipotecas impagas, en general como contra-publicidad sobre los rostros felices del marketing de los bancos. Esa misma estrategia es la que se lleva a que frente a cada escrache, con el micrófono abierto que permite a cada afectado dar testimonio de su caso. Al igual que el kit de escraches, estas imágenes (en formato y con diseño de postal) pueden descargarse libremente de la web de la PAH.

- Señalizar los bancos: Una de las primeras acciones de la PAH para señalizar los bancos, y que continua activa, fue la pegatina que decía (en castellano y catalán): "Que se sepa, este banco estafa, engaña y echa a la gente de su casa”. El fondo en color verde, elegido estratégicamente para que se destacara visualmente del ruido visual y de los colores de la gráfica de los bancos, sería el verde que luego aparecería en el logo de la PAH, en las camisetas y que terminaría identificando al movimiento.

Pero en torno a las manifestaciones de la PAH se han desplegado otros recursos gráficos, que se suman a la intención de señalizar la responsabilidad de las entidades bancarias y los beneficios en la especulación inmobiliaria. En acciones propias de la guerrilla comunicacional, se han intervenido los nombres de los bancos, convirtiendo Santander en Satán, o La Caixa en Mordor (la tierra del mal en la saga del Señor de los Anillos), por ej. O pegando imágenes de zapatos sobre las vitrinas (en alusión a la ofensa que implica arrojarle un zapato a alguien en gran parte del mundo árabe).

Pero no solo aparecen intervenciones simbólicas y (nuevamente) con cierta dosis de humor e ironía, sino que se incorpora información respecto de las tasas de beneficio en momentos de crisis, cantidad de desahucios operados por esa entidad, etc.

- Reflectantes: Siguiendo en la línea de superhéroes, los reflectantes son personajes que, desde 2012, aparecen en diversas manifestaciones. El principio del reflectante es que precisamente, no posee superpoderes que lo vuelven invencible, sino que son los atributos y accesorios los que, en colectivo, lo transforman en un personaje que se distingue del resto.

Los accesorios, objetos y escudos metalizados reflejan la crisis y la violencia que quieren devolver a quienes las han generado, pero también tienen una función práctica: obstaculizar el registro fotográfico (al refractar la luz y disfrazar los cuerpos) y canalizar la indignación a través del humor. Apelan a la teatralización de escenas en las que, por ejemplo, banqueros malvados arrojan su deuda al resto de la manifestación y los superhéroes reflectantes los neutralizan devolviéndosela.

Estas acciones van acompañadas de otras campañas como Fiesta en Bankia o BancaBruta, convocatoria (en las vísperas del segundo aniversario del 15M) a cerrar las cuentas en los bancos comerciales y pasar los depósitos a la banca ética. 


\section{Conclusiones}

En este trabajo revisamos el contexto de surgimiento de cada organización, para rastrear los fundamentos de la práctica del escrache en relación con una forma específica de organización política. La apropiación y la resignificación del escrache como herramienta (y no como mera forma) nos ayuda a entender por qué funciona también para la PAH en el momento específico de discusión de la ILP.

Por otra parte, la puesta en relación con otras políticas visuales ligadas, en el primer caso, a las organizaciones de DDHH en Argentina, y en el segundo, a la problemática de la vivienda, nos permitió entender como se consolidan las escenas de enunciación y los recursos expresivo con los que se relaciona cada escrache.

Cuando el escrache es entendido como forma, lo que se produce es la réplica de un método vacío, es decir: se transforma en un acto conservador. Por esto, el escrache no debe considerarse una técnica universal aplicable a distintos casos, sino una hipótesis práctica (Colectivo Situaciones, 2002), generada mediante un proceso de protagonismo social genuino. Pensarlo como "hipótesis" implica que debe evaluarse y corregirse permanentemente. Por otra parte, el escrache busca generar lazos sociales, a la vez que produce formas materiales de intervención política, en diálogo con otras manifestaciones de nuevo protagonismo social.

Recuperamos la discusión de Butler (2011) a partir de la noción de espacio públicoespacio de la política de Arendt para destacar que si la aparición en la escena pública es la condición para la acción política, ningún cuerpo establece el espacio de aparición, sino que este ejercicio performativo sólo ocurre en el espacio 'entre' cuerpos. "De esta manera, mi cuerpo no actúa solo cuando actúa políticamente. De hecho, la acción surge del "entre"” (Butler, 2011, s/p). Ese entre no es un espacio vacío, sino el espacio de subjetivación de las alianzas, espacio sustentador y a la vez efecto de ellas. En otras palabras, el espacio generado por la organización.

Teatralidad y performance, activismo artístico, ritualidad social de la movilización, sirven también para comprender un acceso al espacio público negado a quienes, desde el poder se concibe como víctimas (hijo de desaparecidos) o como estigmatizado (endeudado) y no como sujetos políticos (H.I.J.O.S.- PAH) constituidos, precisamente, a partir de esas alianzas. El activismo artístico produce estas formas materiales de intervención política ya no como ilustración de un contenido, ni desde el rol del artista como colaborador y/o enunciador privilegiado, sino desde la misma práctica política.

\section{Notas:}

\footnotetext{
${ }^{1}$ Sin embargo, es importante destacar que el relato de esta experiencia (y su inscripción dentro de una genealogía del activismo artístico en nuestro país) es relativamente nuevo. La recuperación y reconstrucción del acontecimiento por parte de teóricos, artistas participantes y testigos se inició casi dos décadas después del Siluetazo (Longoni \& Bruzzone, 2008) cuando todavía eran una serie de imágenes fotográficas, recortes y recuerdos fragmentarios, aunque potentes.
} 


\section{Referencias}

Alemany, A., \& Colau, A. (2013). Vidas hipotecadas: de la burbuja immobiliaria al derecho a la vivienda. Barcelona: Cuadrilátero de libros.

Butler, J. (2011). Bodies in Alliance and the Politics of the Street. European institute for progressive cultural policies. Recuperado el 10 de junio de 2013, de EIPCP (european institute for progressive cultural policies): http: / / eipcp.net/transversal/1011/butler/en

Colectivo Situaciones. (2002). Genocida en el barrio: Mesa de Escrache Popular. Buenos Aires: Ediciones De Mano en Mano.

Creisher, A. \& Sickmann, A. (2006). Ex-Argentina. Pasos para huir del trabajo al hacer. Buenos Aires: Goethe Institut- Interzona Editora.

Expósito, M., Vindel, J. \& Vidal, A. (2012). Activismo artístico. En AAVV, Perder la forma humana. Una imagen sísmica de los años ochenta en América Latina (pp. 43-50). Madrid: Museo Nacional Centro de Arte Reina Sofia.

Holmes, B. (2009). Escape the overcode: Activist art in the control society. Van Abbemuseum.

Longoni, A. (2005). ¿Tucumán sigue ardiendo? Brumaria (5), p.p. 227-244.

Longoni, A. (2007). Encrucijadas del arte activista en Argentina. Ramona (74), p.p 31-43

Longoni, A. (2010). Fotos y Siluetas: dos estrategias en la representacion de los desaparecidos. Emilio

Crenzel (comp.). Los desaparecidos en la Argentina. Memorias, representaciones e ideas (19832008), p.p.35-57.

Longoni, A., \& Bruzzone, G. A. (2008). El siluetazo. Buenos Aires: Adriana Hidalgo Editora.

Rafaelas Carras (GAC). (2009). Pensamientos, prácticas y acciones del GAC. Buenos Aires: Tinta Limón. Rancière, J. (2010). El espectador emancipado. Buenos Aires: Manantial.

Schindel, E. (2008). Siluetas, Rostros, Escraches: Memoria y Performance alrededor del Movimiento de Derechos Humanos. En A. Longoni \& G. A. Bruzzone (Eds.), El Siluetazo (pp. 411-425). Buenos Aires: Adriana Hidalgo Editora.

Svampa, M. (2010). Movimientos Sociales, matrices socio-políticos y nuevos escenarios en América Latina. One World perspectives. Working papers (01) Kassel: Universitätsbibliothek Kassel. https: / / kobra.bibliothek.uni-kassel.de/bitstream/urn:nbn:de:hebis:34-2010110334865/1/ OWP_Working_Paper_2010_01.pdf issn: 1863-0928

Taylor, D. (2002). «You are here»: the DNA of performance. TDR/The Drama Review, 46(1), p.p.149169.

Taylor, D. (2006). Trauma and performance: lessons from Latin America. PMLA, p.p. 1674-1677. Verbitsky, H. (1995). El vuelo. Buenos Aires: Planeta.

Zibechi, R. (2003). Genealogía de la revuelta: Argentina: la sociedad en movimiento. Buenos Aires: Letra libre.

Zuckerfeld, F. (2008).Continuidad de la línea en el trazo: de la Silueta a la Mancha En Longoni, A. \& Bruzzone, G.A. (Eds.), El Siluetazo (pp. 427-454). Buenos Aires: Adriana Hidalgo Editora.

Recibido: 30 de abril / Aprobado: junio 1 de 2015 